\title{
KARAKTERISTIK KULIT KOPI ROBUSTA HASIL SAMPING PENGOLAHAN METODE KERING DARI PERKEBUNAN KOPI RAKYAT DI JAWA TIMUR
}

\author{
Characteristics of Robusta Coffee Husk Obtained from Dry Processing Method of \\ Smallholder Coffee Plantation in East Java \\ Danu Indra Wardhana ${ }^{1}$, Eka Ruriani ${ }^{2}$, Ahmad Nafi $^{3}$ \\ 1,Program Studi Teknologi Industri Pertanian, Fakultas Pertanian, UM Jember \\ ${ }^{2,3}$ Fakultas Teknologi Pertanian, Universitas Jember \\ e-mail: ${ }^{1}$ danuindra@unmuhjember.ac.id, ${ }^{2}$ rurianiftp@yahoo.com, ${ }^{3}$ ama_nafi@yahoo.com
}

\begin{abstract}
ABSTRAK
Produktivitas tanaman kopi di Indonesia cukup tinggi, agroindustri kopi dapat menghasilkan kulit kopi sekitar 60\% dari bahan awal. Penelitian ini bertujuan untuk mengetahui karakteristik kulit kopi perkebunan rakat dari tiga daerah sentra penghasil kopi di Jawa Timur, yaitu Jember, Banyuwangi, dan Malang. Beberapa karakteristik yang dianalisis adalah kadar proksimat(air, abu, lemak, protein dan karbohidrat), kadar serat kasar dan kadar lignoselulosa (lignin, selulosa, dan hemiselulosa). Hasil penelitian menunjukkan bahwa kulit kopi memiliki karakteristik yang berbeda pada setiap daerah. Kulit Kopi dari daerah Jember memiliki kadar air $8,59 \%$, kadar abu 6,93\%, kadar lemak 0,88\%, kadar protein 6,77\%, kadar karbohidrat 76,83\%, kadar serat kasar 30,15\%, kadar lignin 21,95\%, kadar hemiselulosa 11,65\%, dan kadar selulosa 27,26\%. Kulit kopi dari daerah Banyuwangi memiliki kadar air 8,83\%, kadar abu 11,88\%, kadar lemak 0,93\%, kadar protein 7,82\%, kadar karbohidrat 70,54\%, kadar serat kasar 36,98\%, kadar lignin 35,90\%, kadar hemiselulosa 2,50\%, dan kadar selulosa 10,15\%. Kulit kopi dari daerah Malang memiliki kadar air 8,47\%, kadar abu 5,60\%, kadar lemak 1,10\%, kadar protein 7,99\%, kadar karbohidrat 76,83\%, kadar serat kasar 32,38\%, kadar lignin 33,79\%, kadar hemiselulosa $6,34 \%$, dan kadar selulosa $15,38 \%$.
\end{abstract}

Kata kunci: Kulit kopi, Karakteristik, Jawa Timur.

\section{ABSTRACT}

Productivity of coffee plants in Indonesia is quite high, coffee agroindustry resulted coffee husk for about $60 \%$ from its raw material. This research purpose to investigate the characteristics of the three different coffee husks based on its origin smallholder plantation in East Java, those are Jember, Banyuwangi, and Malang. Some of the characteristics analyzed were proximate contents (water moisture, ash, protein, fat, and carbohydrate), crude fiber content, and lignocellulose contents (lignin, cellulose, and hemicellulose). The results showed that coffee husk has different characteristics in each region. Coffee husk from Jember has a 8,59\% of water content, $6,93 \%$ ash content, $0,88 \%$ fat content, $6,77 \%$ protein content, $76,83 \%$ of carbohydrate content, 30,15\% crude fiber content, $21,95 \%$ lignin content, 11,65\% of hemicellulose content, and 27,26\% cellulose content. Coffee husk from Banyuwangi has a $8.83 \%$ of water content, $11.88 \%$ ash content, $0,93 \%$ fat content, $7.82 \%$ protein content, $70.54 \%$ of carbohydrate content, 
$36.98 \%$ crude fiber content, $35.90 \%$ lignin content, $2.50 \%$ of hemicellulose content, and $10.15 \%$ cellulose content. Coffee husk from Malang area has a $8.47 \%$ of water content, $5.60 \%$ ash content, $1.10 \%$ fat content, $7.99 \%$ protein content, $76.83 \%$ of carbohydrate content, $32.38 \%$ crude fiber content, $33.79 \%$ lignin content, $6.34 \%$ of hemicellulose content, and $15.38 \%$ cellulose content.

Keywords: Coffe husk, Characteristics, East Java.

\section{PENDAHULUAN}

Indonesia merupakan negara penghasil kopi terbesar ketiga setelah Brazil dan Vietnam, dimana sebagian besar kopi yang diekspor merupakan jenis robusta. Pada tahun 2013 diperkirakan produktivitas rata-rata kopi di Indonesia mencapai $760 \mathrm{Kg} / \mathrm{Ha}$ dan pada tahun 2014 diperkirakan produktivitas rata-rata kopi di Indonesia mengalami peningkatan mencapai 791 $\mathrm{Kg} / \mathrm{Ha}$ (Direktorat Jenderal Perkebunan, 2012). Provinsi Jawa Timur sebagai salah satu provinsi yang memberi kontribusi cukup tinggi terhadap produksi kopi nasional memiliki luas area perkebunan 51620 ha dengan total produksi 27852 ton. Di Jawa Timur terdapat enam kabupaten/kota penghasil kopi terbesar, yaitu Malang, Banyuwangi, Jember, Lumajang, Pasuruan dan Bondoswoso (BPS Jawa Timur, 2011). Franca dan Oliveira (2012) menyatakan bahwa dalam produksi setiap kilogram biji kopi, diperkirakan dihasilkan 1 kg kulit kopi. Sejumlah besar kulit kopi hasil samping perkebunan rakyat belum dieksplorasi secara maksimal, sehingga sumber daya alam yang potensial tersebut hanya menjadi sampah yang terakumulasi (Wu et al., 2011). Perkebunan rakyat hanya menjual kulit kopi tersebut dengan haraga murah untuk pakan ternak atau digunakan sebagai tambahan pupuk pada tanaman kopi. Menurut Richana (2002) besarnya limbah kulit kopi yang dihasilkan perkebunan rakyat jika tidak dimanfaatkan dengan baik maka akan terbuang percuma dan menimbulkan pencemaran.

Komponen utama dalam kulit kopi yang sangat potensial ialah karbohidrat, serat kasar, dan lignoselulosa. Menurut Taherzadeh dan Karimi (2007) sumber biomassa lignoselulosa yang berasal dari limbah pertanian antara lain jerami, tongkol jagung, kulit buah kakao, dan kulit buah kopi. Kandungan karbohidrat dan serat kasar yang tinggi dari kulit kopi sangat berpotensi digunakan sebagai bahan bahan penelitian berbasis polisakarida.. Komponen lignoselulosa yang tersusun atas selulosa, hemiselulosa, dan lignin sangat berpotensi sebagai bahan baku produkproduk komersial, karena kandungan selulosa dan hemiselulosa pada kulit kopi dapat dikonversi menjadi berbagai produk bernilai ekonomis tinggi, misalnya: enzim, gula pereduksi, furfural, etanol, protein dan asam amino, karbohidrat, lipid, asam organik, fenol, karbon aktif, komposit dari biodegradable plastic, kosmetik, biosorbent, resin, obat-obatan, pangan dan pakan, metana, biopromoters, metabolit sekunder, dan surfaktan (Foyle et al., 2007; Galbe dan Zacchi. 2007; Anindyawati. 2009.). Kulit kopi dapat menghasilkan bioetanol sebesar 51,02\% dengan kadar $38,68 \%$ setelah melalui proses hidrolisis dan fermentasi (Siswati et al.,2010). Keuntungan proses konversi lignoselulosa menjadi berbagai produk juga dapat mengurangi permasalahan pencemaran lingkungan akibat akumulasi limbah biomassa pertanian yang tidak dimanfaatkan secara optimal. Tujuan dari penelitian ini adalah mengetahui karakteristik kimia kulit kopi dari tiga daerah sentra penghasil kopi terbesar di Jawa Timur yaitu Jember, Banyuwangi, dan Malang. 


\section{METODE PENELITIAN}

Penelitian dilakukan dibeberapa tempat laboratorium yang tersaji pada Tabel 1 . Tabel 1. Tempat pelaksanaan penelitian

\begin{tabular}{|c|c|c|c|}
\hline No & Laboratorium & Instansi & Kegiatan \\
\hline 1 & $\begin{array}{l}\text { Rekayasa Proses Hasil } \\
\text { Pertanian }\end{array}$ & $\begin{array}{l}\text { Jurusan THP FTP } \\
\text { Universitas Jember }\end{array}$ & $\begin{array}{l}\text { Pengecilan ukuran dan } \\
\text { pengeringan }\end{array}$ \\
\hline 2 & $\begin{array}{l}\text { Kimia dan Biokimia } \\
\text { Pangan Hasil Pertanian }\end{array}$ & $\begin{array}{l}\text { Jurusan THP FTP } \\
\text { Universitas Jember }\end{array}$ & $\begin{array}{l}\text { Analisis proksimat dan serat } \\
\text { kasar }\end{array}$ \\
\hline 3 & Analisa Terpadu & $\begin{array}{l}\text { Jurusan THP FTP } \\
\text { Universitas Jember }\end{array}$ & Hidrolisis asam kulit kopi \\
\hline 4 & Bioindustri & $\begin{array}{l}\text { Departemen TIN FATETA } \\
\text { IPB }\end{array}$ & $\begin{array}{l}\text { Preparasi total gula dan gula } \\
\text { pereduksi }\end{array}$ \\
\hline 5 & $\begin{array}{l}\text { Dasar-Dasar Ilmu } \\
\text { Teknologi }\end{array}$ & $\begin{array}{l}\text { Departemen TIN FATETA } \\
\text { IPB }\end{array}$ & Analisis lignoseluolsa \\
\hline 6 & Teknik Kimia & $\begin{array}{l}\text { Departemen TIN FATETA } \\
\text { IPB }\end{array}$ & Analisis lignoselulosa \\
\hline
\end{tabular}

Bahan baku dalam penelitian ini adalah kulit kopi robusta hasil samping pengolahan metode kering dari perkebunan kopi rakyat Kecamatan Tanggul Kabupaten Jember, Kecamatan Tirtoyudo Kabupaten Malang, dan Kecamatan Kalibaru Kabupaten Banyuwangi. Bahan kimia yang digunakan meliputi $\mathrm{H}_{2} \mathrm{SO}_{4}, \mathrm{NaOH}$, EDTA, CTAB, $\mathrm{K}_{2} \mathrm{SO}_{4}, \mathrm{Na}_{2} \mathrm{SO}_{4}$, Aseton Teknis, $\mathrm{CuSO}_{3}$, Asam Borat $\left(\mathrm{H}_{3} \mathrm{BO}_{3}\right)$, indikator Mengsel, Petroleum Benzen, $\mathrm{NaOH}$, Etanol, K-Na Tartarat, dan Akuades. Peralatan yang digunakan dalam penelitian ini diantaranya adalah hammer mill, alumunium foil, oven, peralatan gelas, pompa vakum, tanur, kompor listrik, filter glass $2 \mathrm{G}-3$ dan $2 \mathrm{G}-4$, ayakan Tyler 60 mesh, neraca analitik, tabung buret, destilator, tabung kjeldahl.

Penelitian ini dilakukan dalam beberapa tahap, yaitu pengeringan kulit kopi, pengecilan ukuran kulit kopi, dan karakterisasi kimia kulit kopi. Bahan baku kulit kopi yang digunakan sebagai sampel ada tiga, yaitu kulit kopi pengolahan kering dari perkebunan rakyat di daerah Jember, Banyuwangi, dan Malang untuk mengetahui keragaman bahan baku terhadap karakteristik proksimat, serat kasar, dan lignoselulosa masing-masing sampel kulit kopi pengolahan kering dari tiga daerah sentra penghasil kopi terbesar di Jawa Timur. Proses pengeringan kulit kopi dilakukan dengan menggunakan sinar matahari selama \pm 2 hari hingga diperoleh kadar air 8-9\% Pengecilan ukuran kulit kopi dilakukan menggunakan hammer mill hingga diperoleh ukuran 60 mesh. Selanjutnya dilakukan karakterisasi kimia terhadap sampel kulit kopi tersebut.

Penelitian ini diolah secara deskriptif dengan masing-masing perlakuan dilakukan pengulangan sebanyak tiga kali. Data hasil analisis disajikan dalam bentuk 
ilustrasi tabel, grafik, dan histogram untuk mempermudah interpretasi data. Pengamatan yang dilakukan adalah kadar air (Sudarmadji et al., 1997), kadar abu (Sudarmadji et al., 1997), kadar lemak (Sudarmadji et al., 1997), kadar protein (Sudarmadji et al., 1997), kadar karbohidrat (Winarno, 2002), kadar serat kasar (Sudarmadji et al., 1997), kadar lignin (Apriantono et al., 1989), kadar selulosa (Apriantono et al., 1989), dan kadar hemiselulosa (Apriantono et al., 1989).

\section{HASIL DAN PEMBAHASAN}

\section{Karakteristik Kulit Kopi}

Karakteristik bahan baku kulit kopi yang sangat penting diketahui adalah analisis proksimat, analisis serat kasar dan analisis lignoselulosa. Analisis proksimat bahan baku meliputi kadar air, kadar abu, kadar lemak, kadar protein, dan kadar karbohidrat, sedangkan Analisis lignoselulosa meliputi kadar lignin, kadar selulosa, dan kadar hemiselulosa.

\section{Analisis Proksimat}

Hasil analisis proksimat kulit kopi dari daerah Jember, Banyuwangi, dan Malang ditunjukkan pada Gambar 1.

Analisis proksimat dilakukan dengan beberapa parameter berupa kadar air, kadar abu, kadar lemak, kadar protein, kadar karbohidrat (by difference). Kadar proksimat bahan baku dapat menunjukkan potensi diversifikasi suatu produk. Hasil penelitian menunjukkan kadar proksimat paling tinggi bahan baku adalah kadar karbohidrat, sedangkan kadar proksimat terendah adalah kadar lemak (Gambar 1).

\section{Kadar Air}

Kadar air perlu dianalisis karena kadar air sangat berpengaruh terhadap mutu dan daya simpan bahan. Semakin tinggi kadar air suatu bahan maka daya simpannya semakin rendah. Kulit kopi yang memiliki kadar air lebih dari 14\% sangat rentan dalam penyimpanannya karena kadar air yang tinggi memberikan peluang yang cukup besar bagi pertumbuhan mikroorganisme terutama kapang yang dapat hidup pada substrat dengan kadar air yang cukup rendah. Menurut Fardiaz (1989), batas kadar air minimum dimana mikroba masih dapat tumbuh adalah $14-15 \%$. 


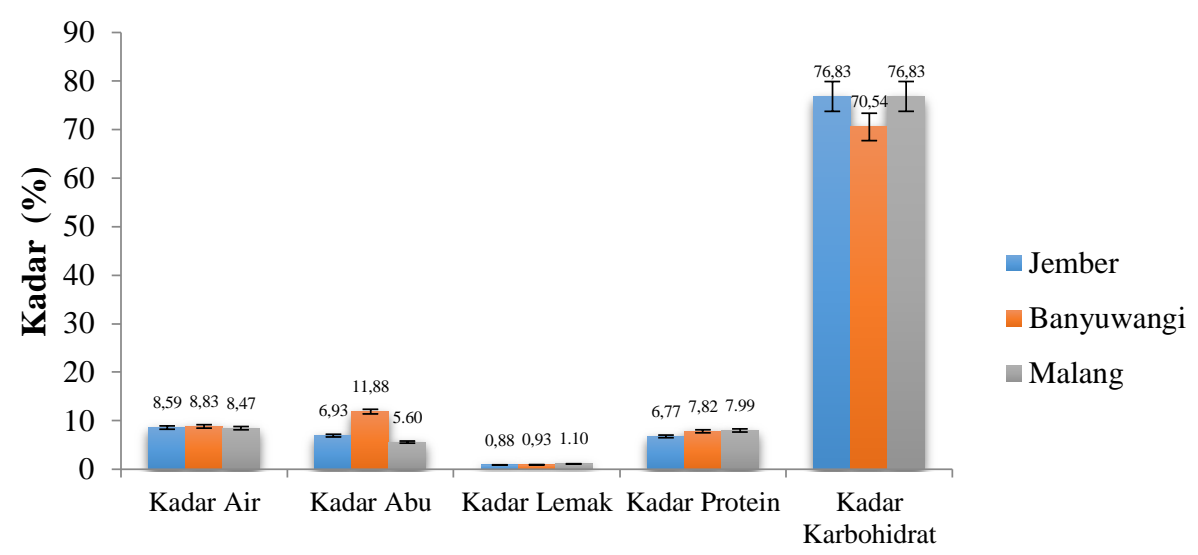

Komponen Proksimat

Gambar 1. Kadar proksimat kulit kopi hasil pengolahan metode kering dari daerah Jember, Banyuwangi, dan Malang

Berdasarkan hasil analisis kadar air yang telah dilakukan diperoleh nilai kadar air sampel kulit kopi daerah Jember, Banyuwangi, dan Malang berturut-turut adalah $8,59 \%, 8,83 \%$, dan 8,47\% (Gambar 1). Kandungan air pada bahan kulit kopi dari daerah Jember, Banyuwangi, dan Malang yang digunakan memiliki nilai yang tidak jauh berbeda berkisar antara 8-9\%. Kandungan air yang cukup rendah disebabkan oleh pengeringan yang dilakukan pada sinar matahari selama \pm 2 hari sebelum bahan dihaluskan menggunakan hammer mill. Jumlah kadar air yang rendah tersebut menandakan kulit kopi tersebut relatif stabil dari serangan mikroba sehingga kulit kopi cukup aman dari kerusakan selama penelitian dilaksanakan.

\section{Kadar Abu}

Berdasarkan hasil analisis kadar abu yang telah dilakukan, diperoleh nilai kadar abu sampel kulit kopi daerah Jember, Banyuwangi, dan Malang berturut-turut adalah $6,93 \%, 11,88 \%$, dan 5,6\%. Analisa kadar abu dilakukan untuk mengetahui kandungan mineral pada bahan pangan (Apriyantono et al., 1989). Unsur-unsur mineral adalah unsur-unsur kimia selain karbon, oksigen, dan nitrogen yang dibutuhkan oleh tubuh (Gaman dan Sherrington, 1981). Kadar abu kulit kopi dari daerah Banyuwangi memiliki kandungan paling tinggi yaitu sebesar $11,88 \%$ dibandingkan daerah Jember dan Malang. Hasil pengukuran kadar abu yang relatif tinggi tersebut menandakan kulit kopi dari Banyuwangi memiliki kualitas yang kurang baik karena telah terjadi kontaminasi antara kulit kopi dengan tanah. Terkontaminasinya kulit kopi dengan tanah sangat mudah terjadi, karena selama ini kulit kopi merupakan bahan hasil samping pengolahan kopi pemanfaatannya masih kurang, sehingga hanya diletakkan diatas tanah dan digunakan sebagai campuran pupuk pada tanaman kopi. 


\section{Kadar Lemak}

Berdasarkan hasil analisis kadar lemak yang telah dilakukan diperoleh nilai kadar lemak sampel kulit kopi daerah Jember, Banyuwangi, dan Malang berturut-turut adalah 0,883\%, 0,925\%, dan 1,1\%. Secara umum kandungan lemak pada kulit kopi tergolong rendah, dari data analisis tersebut dapat diketahui bahwa kadar lemak paling tinggi yaitu sampel kulit kopi dari daerah malang yaitu 1,1\% dan kadar lemak paling rendah adalah sampel kulit kopi dari daerah jember yaitu 0,883\%, Kadar lemak yang rendah akan mempermudah perlakuan pendahuluan bahan untuk mengisolasi lignoselulosa dari biomassa kulit kopi yang digunakan. Perbedaan kandungan lemak kulit kopi dari masing-masing daerah dapat disebabkan karena perbedaan suhu, iklim dan kondisi lingkungan dari tanaman kopi tersebut.

\section{Kadar Protein}

Berdasarkan hasil analisis kadar protein yang telah dilakukan diketahui nilai kadar protein sampel kulit kopi daerah Jember, Banyuwangi, dan Malang berturut-turut adalah $6,77 \%, 7,82 \%$, dan 7,99\%. Kadar protein dari tiga daerah tersebut tergolong rendah dikarenakan hanya berkisar antara 6-8\%.

\section{Kadar Karbohidrat}

Karbohidrat merupakan sumber energi utama bagi manusia dan hewan yang harganya relatif murah. Semua karbohidrat berasal dari tumbuh-tumbuhan melalui fotosintesis (Almatsier, 2006). Hasil perhitungan by difference pada kulit kopi dari masing-masing daerah secara berturut-turut dari Jember, Banyuwangi, dan Malang adalah 76,83\%, 70,54\%, dan 76,83\%.

Karbohidrat merupakan polimer yang tersusun dari molekul gula yang terangkai menjadi rantai yang panjang serta dapat pula bercabang-cabang, disebut polisakarida, misalnya pati, kitin, selulosa, hemiselulosa, dan lignin. Selain monosakarida dan polisakarida, terdapat pula disakarida (rangkaian dua monosakarida) dan oligosakarida (rangkaian beberapa monosakarida). Hasil penelitian menunjukkan kadar karbohidrat dari masing-masing daerah cukup tinggi berkisar 70-80\% (Gambar 1). kulit kopi dari masing-masing daerah sangat berpotensi digunakan sebagai bahan baku penelitian berbasis polisakarida.

\section{Analisis Serat Kasar}


Hasil analisis serat kasar kulit kopi dari daerah Jember, Banyuwangi, dan Malang dapat dilihat pada Gambar 2.

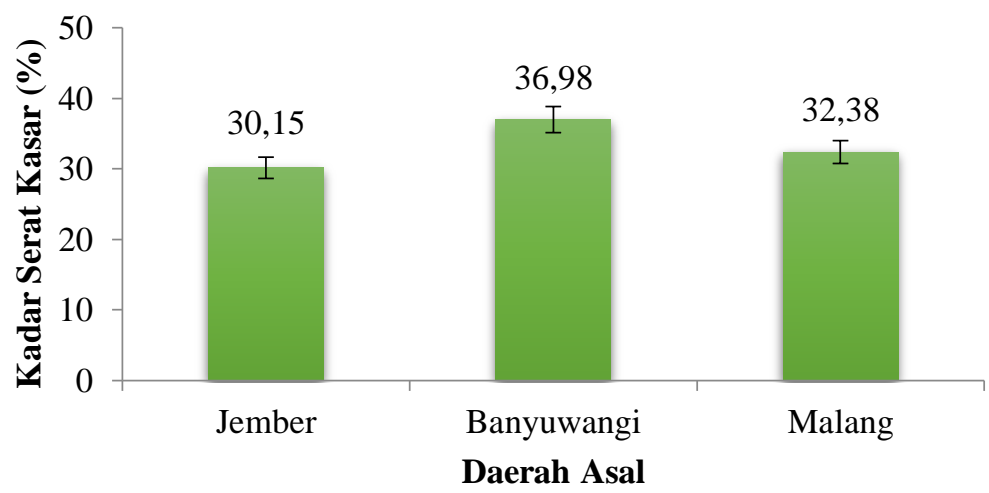

Gambar 2. Kadar serat kasar kulit kopi hasil pengolahan metode kering dari daerah Jember, Banyuwangi, dan Malang

Serat merupakan polisakarida nonpati yang menyatakan polisakarida dinding sel. Terdapat dua golongan serat yaitu yang tidak dapat larut dan dapat arut dalam air (Almatsier, 2006). Kadar serat kasar adalah residu dari bahan makanan atau pertanian setelah diperlakukan dengan asam atau alkali mendidih (Fardiaz, 1989). Total kandungan serat kasar dalam kulit kopi dapat merepresentasikan kandungan lignoselulosanya. Tillman et al., (1998) menyatakan bahwa serat kasar terdiri atas selulosa, hemiselulosa, dan lignin, serta senyawa minor lain seperti pektin. Sehingga total kandungan masing-masing fraksi lignoselulosa (selulosa, hemiselulosa dan lignin) sangat ditentukan oleh total kandungan serat kasar di dalam suatu biomassa. Total kandungan selulosa, hemiselulosa, maupun lignin dapat menurun seiring menurunnya kandungan serat kasar, meskipun kadarnya (persentase) masing-masing mengalami kenaikan.

Hasil penelitian menunjukkan bahwa kandungan serat kasar daerah Jember, Banyuwangi, dan Malang berturut-turut adalah 30,15\%, 36,98\%, dan 32,38\% (Gambar 2) menunjukkan bahwa masing-masing sampel yang diperoleh dari tiga daerah sentra penghasil kopi di Jawa Timur memiliki kadar serta kasar tidak memiliki perbedaan yang cukup signifikan berkisar antara 30-36 \%. Tingginya kadar serat kulit kopi dari masingmasing daerah sangat berpotensi dikembangkan untuk produk-produk yang bahan bakunya berbasis polisakarida.

\section{Analisis Lignoselulosa}

Hasil analisis lignoselulosa kulit kopi dari tiga daerah Jember, Banyuwangi, dan Malang ditunjukkan pada Gambar 3. 


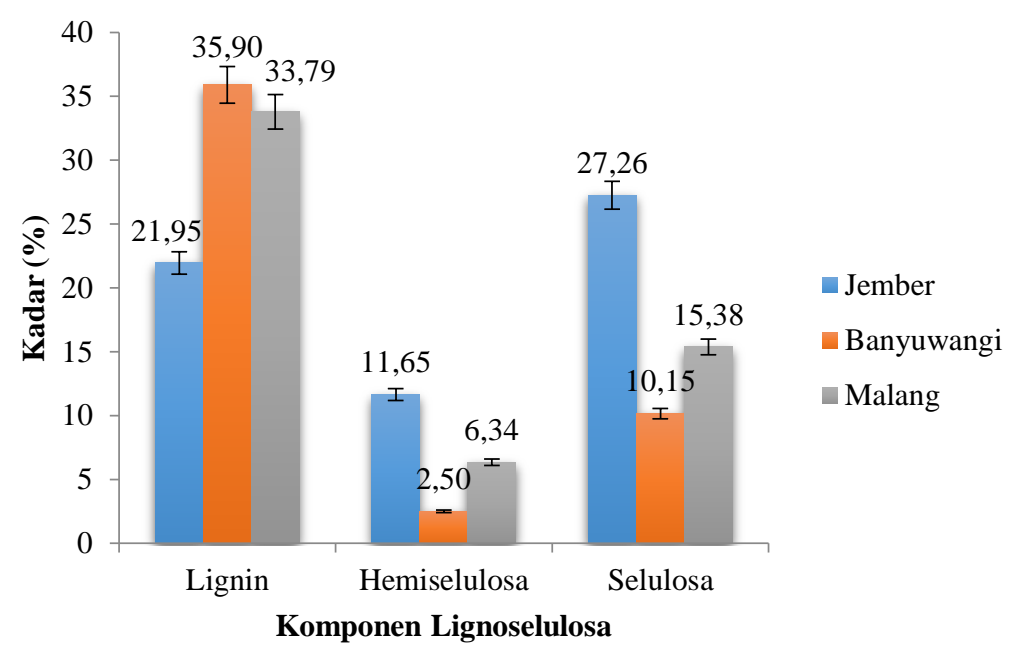

Gambar 3. Kadar lignoselulosa kulit kopi hasil pengolahan metode kering dari daerah Jember Banyuwangi, dan Malang

Bahan lignoselulosa pada umumnya mengandung tiga komponen utama yaitu selulosa, hemiselulosa, dan lignin yang terikat secara kuat. Ketiga komponen tersebut dihasilkan dari proses fotosintesis (Enari, 1983). Kadar masing-masing komponen lignoselulosa pada sampel awal kulit kopi yang diperoleh dari Jember, Banyuwangi, dan Malang terdapat perbedaan satu sama lain tersaji dalam (Gambar 3).

Hasil penelitian menunjukkan kadar lignin kulit kopi dari daerah Jember, Banyuwangi dan Malang berturut-turut adalah 21,6\%, 35,90\%, dan 33,79\% (Gambar 3). Daerah Jember memiliki kadar lignin paling rendah yaitu sebesar 21,6\% dan Banyuwangi memiliki kadar lignin paling tinggi sebesar 35,90\% Kandungan lignin yang tinggi ini dapat menjadi penghalang dalam proses hidrolisis selulosa dan hemiselulosa menjadi senyawa yang lebih sederhana pada proses berikutnya (Ingram et al., 1999). Lignin merupakan polimer tiga dimensi unit fenil propana yang diikat oleh ikatan eter (C-O-C) dan karbon (C-C). Adanya ikatan arilalkil dan eter menyebabkan lignin tahan terhadap hidrolisis (Fengel dan Wegener, 1985).

Kadar selulosa dan hemiselulosa paling tinggi adalah sampel kulit kopi dari daerah Jember yaitu sebesar 27,26\% dan 11,65\% dibandingkan dengan kadar selulosa dan hemiselulosa dari daerah Banyuwangi dan Malang (Gambar 3). Komponen selulosa merupakan mikrofibril dari glukosa yang terikat satu dengan lainnya membentuk rantai polimer yang sangat panjang, hidrolisis sempurna selulosa menghasilkan monomer selulosa yaitu glukosa, sedangkan hidrolisis tak sempurna menghasilkan disakarida dari selulosa yang disebut selobiosa dan selo-oligosakarida (Sun, 2002). Sedangkan hemiselulosa merupakan rantai polimer bercabang dan memiliki struktur yang sangat kompleks karena tersusun dari jenis gula yang beragam (xilosa, manosa, galaktosa, 
rhamnosa dan arabinosa) tersusun atas berbagai intermonomerik (Deobald dan Crawford, 2002).

Kulit kopi dari daerah Jember memiliki potensi paling besar digunakan sebagai bahan baku produk komersial seperti tekstil, kertas, xylitol, dan bioetanol dikarenakan memiliki kadar selulosa dan hemiselulosa tertinggi, dengan tingginya kadar selulosa dan hemiselulosa dari kulit kopi tersebut monomer gula yang dihasilkan juga akan lebih tinggi dibandingkan kulit kopi dari daerah lain. Selain itu kulit kopi dari daerah Jember memiliki kadar lignin yang paling rendah, sehingga sampel tersebut paling mudah dihidrolisis komponen selulosa dan hemiselulosanya dibandingkan dengan kulit kopi dari daerah Banyuwangi dan Malang yang memiliki kadar lignin cukup tinggi.

\section{KESIMPULAN}

Kulit kopi hasil samping pengolahan kering dari perkebunan rakyat daerah Jember, Banyuwangi, dan Malang memiliki karakteristik kimia yang berbeda-beda. Kulit Kopi dari daerah Jember memiliki kadar air 8,59\%, kadar abu 6,93\%, kadar lemak 0,88\%, kadar protein 6,77\%, kadar karbohidrat 76,83\%, kadar serat kasar 30,15\%, kadar lignin 21,95\%, kadar hemiselulosa 11,65\%, dan kadar selulosa 27,26\%. Kulit kopi dari daerah Banyuwangi memiliki kadar air 8,83\%, kadar abu 11,88\%, kadar lemak 0,880,93\%, kadar protein 7,82\%, kadar karbohidrat 70,54\%, kadar serat kasar 36,98\%, kadar lignin 35,90\%, kadar hemiselulosa 2,50\%, dan kadar selulosa 10,15\%. Kulit kopi dari daerah Malang memiliki kadar air 8,47\%, kadar abu 5,60\%, kadar lemak 1,10\%, kadar protein 7,99\%, kadar karbohidrat 76,83\%, kadar serat kasar 32,38\%, kadar lignin $33,79 \%$, kadar hemiselulosa 6,34\%, dan kadar selulosa 15,38\%.

\section{DAFTAR PUSTAKA}

Almatsier, S., 2006, Prinsip Dasar Ilmu Gizi, Gramedia, Jakarta.

Anindyawati, T., 2009, Prospek Enzim dan Limbah Lignoselulosa untuk Produksi Bioetanol. BioScience. Vol. 44, Ed.1, hal 49- 56.

Apriyantono, A., Fardiaz, D., Puspitasari, N. L., Sedamawati dan Budiyanto, S., 1989, Analisis Pangan, PAU Pangan dan Gizi, IPB Press, Bogor.

BPS Jawa Timur, 2011, Data Produktivitas Kopi di Sentra Produksi Terbesar Provinsi Jawa Timur, http//:www.jatim.bps.go.id, diakses tgl 12 Juni 2014.

Deobald, L. A., dan Crawford, D., 2002, Lignocellulose biodegradation, Di dalam: Hurst, Crawford, Kudsen, Mclnerney, \& Stetzenbach, (Ed.), Manual of Enviromental Microbiology, Ed ke-2, ASM Press, Washington.

Direktorat Jenderal Perkebunan, 2012, Produktivitas kopi menurut provinsi di Indonesia 2008 2012,http://www.deptan.go.id/infoeksekutif/bun/BUN-asem2012/Prodtv/Kopi.pdf, diakses tgl 15 April 2014. 
Enari, T. M., 1983, Microbial Cellulase, Di dalam: Fogarty W. M, (Ed), Microbial Enzyme and Biotechnology, Applied Science Publisher, New York.

Fardiaz, S., 1989, Mikrobiologi Pangan I, PAU Pangan dan Gizi, IPB Press, Bogor.

Fengel, D., dan Wegener, G., 1985, Kimia Kayu, Reaksi Ultrastruktur, diterjemahkan oleh Hardjono, S., UGM Press, Yogyakarta.

Foyle, T., Jennings, L., dan Mulcahy, P., 2007, Compositional Analysis of Lignocellulosic Materials: Evaluation of Methods Used for Sugar Analysis of Waste Paper and Straw. Bioresour Technol, Vol. 98, 3026-3036.

Galbe, M., dan Zacchi, G., 2007, Pretreatment of Lignocellulosic Materials for Efficient Bioethanol Production, Adv. Biochem. Eng. Biotechnol, Vol. 108, 41-65.

Gaman, P. M., dan Sherrington, 1981, The Science of Food, Pergamon Press Plc, Oxford.

Herman, 2008, Perkembangan dan Prospek Komoditas Kopi, Tinjauan Komoditas Perkebunan, Lembaga Riset Perkebunan Indonesia, Bogor.

Ingram, Gomez, Lai, Moniruzzaman, Wood, Yamano, dan York, 1999, Metabolic Engineering of Bacteria for Ethanol Production. Journal of Biotechnol and Bioeng, Vol. 58 Ed. 2, 204-214.

Richana, N., 2002. Produksi dan Prospek Enzim Xilanase dalam Pengembangan Bioindustri di Indonesia. Buletin AgroBio, Vol. 5 Ed. 1, 29-36

Sudarmadji, S., Haryono, B., dan Suhardi., 1997, Prosedur Analisa untuk Bahan Makanan dan Pertanian, Liberty, Yogyakarta.

Sun, Y. dan Cheng, J. 2002. Hydrolysis of lignocellulosic material for ethanol production: A review. J Biores Technol 83:1-11.

Taherzadeh, M. J., dan Karimi, K., 2007, Acid-Based Hydrolysis Processes for Ethanol from Lignocellulosic Material: A Review, Journal Biores, Vol.2 Ed.3, 472-499.

Tillman, Hartadi, Reksohadiprodjo, dan Lebdosoekojo, 1998, Ilmu Makanan Ternak Dasar, Fakultas Peternakan, Universitas Gajah Mada Press, Yogyakarta.

Winarno, F. G., 2002, Kimia Pangan dan Gizi, Gramedia Pustaka Utama, Jakarta.

Wu, Zhang, Zeng, Zhang, dan Xiong. 2011. L-Arabinose and Oligosaccharides Production from Sugar Beet Pulp by Xylanase and Acid Hydrolysis. African J Biotechnology, Vol.10, Ed.10, 1907-1912. 